\title{
PENGAMBILAN KEPUTUSAN USAHA MANDIRI MAHASISWA DITINJAU DARI FAKTOR INTERNAL DAN EKSTERNAL
}

\author{
Rina Irawati \\ Dosen STIE Malangkuçeçwara Malang
}

\begin{abstract}
Abstrak
Penelitian ini bertujuan untuk mengetahui keputusan mahasiswa memiliki usaha mandiri STIE Malangkucecwara Malang ditinjau dari faktor internal dan eksternal. Jenis penelitian adalah deskriptif. Sampel penelitian sejumlah 54 orang mahasiswa dari angkatan 2013-2015. Hasil penelitian membuktikan bahwa mayoritas jenis kelamin mahasiswa memiliki usaha mandiri di STIE Malangkucecwara Malang adalah wanita. Faktor internal mahasiswa memiliki usaha mandiri didasarkan atas berani mengambil resiko, internal locus of control, motivasi memiliki pendapatan sendiri, kebutuhan akan kebebasan, dan ide kreatif. Faktor eksternal yang mendorong mahasiswa memiliki usaha mandiri adalah: pengaruh role model, dukungan keluarga dan teman, kesempatan, kepuasan menjalani hidup, dan pendidikan. Keputusan mahasiswa memiliki usaha mandiri didasarkan oleh intuisi, pengalaman, fakta yang terjadi di lapangan, wewenang, dan rasional. Faktor penghambat terbesar dalam berwirausaha adalah kegagalan usaha, dan Faktor pendukung terbesar mahasiswa berwirausaha adalah orang tua. Hasil penelitian ini didukung oleh penelitian terdahulu antara lain: Indarti, Nurul dan Rokhima Rostiani (2008), Yulia, Wasa dan Dwi Endah Kusrini (2010), Zulkifli (2011), Ifham, Ahmad dan Avin Helmi (2011), dan Chasbiansari, Dyas (2007).
\end{abstract}

Kata kunci: Usaha mandiri mahasiswa, Pengambilan Keputusan.

\begin{abstract}
This study aims to determine the decision of students to have independent business STIE Malangkucecwara Malang in terms of internal and external factors. The type of research is descriptive. The sample of this research is 54 students from class of 2013-2015. The results of the study prove that the majority of sex students have independent business in STIE Malangkucecwara Malang is a woman. Internal factors students have independent business based on risk-taking, internal locus of control, self-generated motivation, the need for freedom, and creative ideas. External factors that encourage students to have independent business are: the influence of role models, family and friends support, opportunities, life satisfaction, and education. The results of this study are supported by previous researches: Indarti, Nurul and Rokhima Rostiani (2008), Yulia, Wasa and Dwi Endah Kusrini (2010), Zulkifli (2011), Ifham, Ahmad and Avin Helmi (2011), and Chasbiansari, Dyas (2007).

Keywords: Student self-help, Decision Making.
\end{abstract}

\section{PENDAHULUAN}

Pada tahun 2008 krisis keuangan global melanda dunia yang menyebabkan banyak perusahaan di dunia gulung tikar sehingga terpaksa mem-PHK atau merumahkan karyawannya. Hal ini berdampak bagi masyarakat baik di lapisan atas, menengah dan bawah. Masyarakat semakin sulit memperoleh pendapatan guna memenuhi kebutuhan hidupnya. Tingkat pengangguran semakin bertambah, hargaharga barang naik sedangkan pendapatan masyarakat tetap.

Berdasarkan data terakhir BPS Agustus 2015 (www.mediaindonesia.com), angka pengangguran di Indonesia pada tahun 2015 sebanyak 7,56 juta jiwa. Jumlah angkatan kerja pada Agustus 2015 sebesar 122,38 juta. Hal ini dikarenakan adanya PHK dan daya serap yang agak menurun, sehingga pengangguran meningkat. Jumlah angkatan kerja meningkat, sedangkan daya serap tenaga kerja dari beberapa industri melemah.

Saat ini lapangan pekerjaan di sektor formal semakin berkurang. Sedangkan lulusan sarjana ataupun diploma (sarjana muda) setiap tahun semakin meningkat. Fakta ini membuktikan bahwa pemikiran kreatif dan inovatif para sarjana ini harus lebih banyak dikembangkan agar dapat membuka peluang usaha baru. Tidak hanya bergantung dan berharap penuh dengan pemerintah atau instansi swasta lainnya. Sampai pada saat ini pilihan berwirausaha belum merupakan lapangan pekerjaan yang diminati dan dinanti bagi para sarjana yang sedang mencari pekerjaan. Banyak lulusan sarjana yang lebih sebagai pencari kerja (job seeker) daripada pencipta kerja (job creator). Padahal dunia 
wirausaha merupakan pilihan yang rasional dalam situasi dan kondisi yang tidak bisa diandalkan ini. Tetapi dengan adanya suatu persepsi negatif yang memunculkan image buruk bahwa wirausaha itu adalah pekerjaan yang kurang menjanjikan dan memberi tantangan besar, mengakibatkan banyak orang kurang berani melakukan wirausaha. Persepsi negatif ini sebenarnya berupa keyakinankeyakinan subyektif yang tidak mengandung kebenaran obyektif. Prasangka buruk ini disebut dengan mitos, dan mitos ini harus segera dihilangkan (Ifham, 2010).

Kewirausahaan saat ini sedang gencar dilakukan terutama di dunia pendidikan. DIKTI (Dirjen Pendidikan Tinggi) mencanangkan program kewirausahaan mahasiswa menjadi prioritas (Irwandi, 2009 dalam Yulia, 2010). Hal ini sebagai upaya pembenahan sistem pendidikan agar terjadi keselarasan antara pendidikan dan dunia kerja. Peranan perguruan tinggi diperlukan untuk memberikan informasi, pengetahuan, pemahaman tentang kewirausahaan serta memberikan wadah bagi mahasiswa untuk berwirausaha.

STIE Malangkucecwara Malang sejak tahun 2009 sudah memasukkan mata kuliah Kewirausahaan dan Mega Creativity dalam kurikulum pembelajaran. Mata kuliah itu diberlakukan sebagai mata kuliah wajib untuk merubah mindset mahasiswa dari job seeker menjadi job creator dan membekali mahasiswa menyusun sebuah proposal bisnis. Mahasiswa setiap tahun juga dimotivasi untuk mengikuti ajang Program Kreativitas Mahasiswa Kewirausahaan (PKM-K) yang diselenggarakan oleh DIKTI atau mengikuti program CSR dari Bank Mandiri yaitu Wirausaha Muda Mandiri. Hal ini tentu saja mendorong mahasiswa untuk lebih berpikir kreatif dan inovatif dalam menciptakan produk yang berdaya jual, sehingga dapat membuka bisnis baru dan menambah lapangan pekerjaan. Dengan berwirausaha diharapkan ketergantungan untuk bekerja di sektor formal akan berkurang.

Saat ini banyak mahasiswa STIE Malangkucecwara Malang yang mengambil keputusan untuk memiliki usaha mandiri (berwirausaha) di samping kuliah. Pengambilan keputusan merupakan suatu proses pemilihan alternatif terbaik dari beberapa alternatif secara sistematis untuk digunakan sebagai cara pemecahan masalah. Sedangkan kewirausahaan (usaha mandiri) adalah semangat, sikap, perilaku kemampuan seseorang dalam menangani usaha dan kegiatan yang mengarah pada upaya mencari, menciptakan, menerapkan cara kerja, teknologi dan produk baru dengan meningkatkan efisiensi dalam memberikan pelayanan yang lebih baik dan memperoleh keuntungan yang lebih besar (http://akhmadsudrajat.wordpress.com, 2010). Keputusan memiliki usaha mandiri ini didasari oleh faktor internal dan faktor eksternal. Faktor internal merupakan dorongan untuk melakukan wirausaha yang berasal dari dalam diri mahasiswa, sedangkan faktor eksternal merupakan dorongan untuk melakukan wirausaha yang berasal dari luar diri mahasiswa (Utami, 2007 dalam Yulia, 2010).

Rumusan masalah penelitian ini adalah: (1) Bagaimana keputusan memiliki usaha mandiri mahasiswa STIE Malangkucecwara Malang ditinjau dari faktor internal?; dan (2) Bagaimana keputusan memiliki usaha mandiri mahasiswa STIE Malangkucecwara Malang ditinjau dari faktor eksternal?. Adapun manfaat penelitian adalah: (1) Sebagai bahan masukan bagi pihak manajemen STIE Malangkucecwara Malang untuk menyempurnakan kurikulum terutama mata kuliah Kewirausahaan; (2) Sebagai bahan masukan bagi mahasiswa STIE Malangkucecwara mengenai faktor-faktor yang menjadi keputusan mereka memiliki usaha mandiri; (3) Untuk mengetahui sejauh mana aplikasi mahasiswa terhadap keputusan memiliki usaha mandiri setelah memperoleh teori/ilmu di bangku kuliah; dan (4) Sebagai bahan acuan (referensi) dalam penelitian selanjutanya dengan menambah variabel penelitian atau menggunakan metode analisis yang lain.

\section{TINJAUAN PUSTAKA \\ Tinjauan Penelitian Terdahulu}

Indarti, Nurul dan Rokhima Rostiani (2008) meneliti terhadap 332 pelajar dari tiga perguruan tinggi di tiga negara berbeda yaitu Indonesia, Jepang dan Norwegia yang menunjukkan bahwa keinginan mahasiswa berwirausaha dan faktor-faktor yang mempengaruhinya berbeda di masing-masing negara. Hasil penelitian membuktikan bahwa selfefficacy menjadi faktor kunci yang mempengaruhi minat berwirausaha pada mahasiswa Norwegia. Latar belakang pendidikan menjadi faktor utama pada mahasiswa Indonesia. Penelitian Yulia, Wasa dan Dwi Endah Kusrini (2010) yang mengambil obyek mahasiswa berwirausaha di 
ITS Surabaya membuktikan bahwa hanya sebagian kecil saja mahasiswa yang menjalankan usaha sampingan selain kuliah, sebagian besar berasal dari luar Surabaya, tingkat IPK berkisar 3.00 - 3.50, dan banyak di antara mereka yang pernah mengikuti kegiatan kewirausahaan tetapi tidak pernah punya pengalaman berwirausaha. Variabel IPK, kepribadian berani mengambil resiko, evaluasi diri dan pengaruh lingkungan keluarga secara signifikan berpengaruh terhadap kemepilikan usaha mandiri mahasiswa ITS.

Zulkifli (2011) meneliti tentang faktorfaktor yang mempengaruhi keberhasilan dan kegagalan seorang wirausaha dihubungkan dengan pemilihan bidang usaha. Hasil penelitian membuktikan bahwa faktor tersebut adalah kepercayaan diri, orientasi terhadap tugas dan hasil, berani mengambil resiko, kepemimpinan dan orisinalitas. Sedangkan penelitian Ifham, Ahmad dan Avin Helmi (2011) meneliti tentang hubungan kecerdasan emosi dan kewirausahaan pada mahasiswa. Hasil penelitian menunjukkan bahwa kecerdasan emosi meliputi: emotional literacy, emotional fitness, emotional depth, dan emotional alchemy. Sedangkan kewirausahaan meliputi: kemampuan melihat peluang bisnis, memiliki kepercayaan diri dan berperilaku baik terhadap dirinya dan lingkungan, gaya kepemimpinan, adanya inisiatif, kreativitas dan inovasi, mampu menjadi pekerja keras, memiliki visi yang luas dan optimisme tinggi, berani mengambil resiko, dan sensitif terhadap kritik membangun. Penelitian Chasbiansari, Dyas (2007) membuktikan bahwa terdapat hubungan positif dan signifikan antara kompetensi sosial dan kewirausahaan pada mahasiswa Universitas Diponegoro Semarang.

\section{Pengambilan Keputusan}

Menurut Williams (2001) pengambilan keputusan adalah proses memilih suatu pemecahan masalah dari beberapa alternatif yang tersedia. Sule (2008) menyatakan bahwa pengambilan keputusan merupakan proses memilih satu penyelesaian dari beberapa alternatif yang ada. Maka dapat disimpulkan bahwa pengambilan keputusan merupakan memilih dan menetapkan satu alternatif yang dianggap paling menguntungkan dari beberapa alternatif yang dimiliki. Alternatif yang ditetapkan merupakan keputusan. Kualitas keputusan yang diambil tersebut merupakan standar dari efektivitas mereka.

Stoner, Freeman dan Gilbert (1995) dalam Sule (2008) menjelaskan bahwa proses pengambilan keputusan adalah: (1) Investigasi situasi, meliputi: identifikasi masalah, diagnosis penyebab masalah, dan identifikasi tujuan dari penyelesaian masalah melalui keputusan yang akan diambil; (2) Penentuan alternatif; (3) Penilaian alternatif; dan (4) Implementasi dan pengawasan.

Terdapat enam tahap proses pengambilan keputusan rasional menurut Williams (2001) yaitu: (1) Mendefinisikan masalah, (2) Mengidentifikasi kriteria keputusan, (3) Menimbang kriteria, (4) Membuat alternatif pilihan tindakan, (5) Mengevaluasi setiap alternatif, dan (6) Memperkirakan keputusan yang paling optimal. Siswanto (2008) mengemukakan pendapat bahwa proses pengambilan keputusan meliputi: (1) Penetapan tujuan spesifik serta pengukuran hasilnya, (2) Identifikasi permasalahan, (3) Pengembangan alternatif, (4) Evaluasi alternatif, (5) Seleksi alternatif, (6) Implementasi keputusan, serta (7) Pengendalian dan evaluasi.

Sementara itu, George R. Terry (dalam Sudrajad, 2010) menyebutkan 5 dasar (basis) dalam pengambilan keputusan, yaitu: (1) intuisi; (2) pengalaman; (3) fakta; (4) wewenang; dan (5) rasional.

\section{Usaha Mandiri (Kewirausahaan)}

Alma (2005) menyatakan bahwa istilah kewirausahaan berasal dari terjemahan Entrepreneurship yang diterjemahkan sebagai "perantara". Wirausaha sendiri berasal dari bahasa Perancis, entrepreneur yang artinya adalah "antara". Menurut Meredith (2000), seorang wirausaha atau entrepreneur adalah orang yang mempunyai kesempatan melihat dan menilai kesempatan-kesempatan bisnis, mengumpulkan sumber-sumber daya yang dibutuhkan guna mengambil keuntungan daripadanya dan mengambil tindakan yang tepat guna memastikan sukses.

As'ad (2002) mengemukakan bahwa wirausahawan adalah individu yang memiliki kemampuan dan sikap mandiri, kreatif, inovatif, ulet, berpandangan jauh ke depan, pengambilan resiko yang sedang dan tanpa mengabaikan orang lain dalam bidangnya atau masyarakat. Sedangkan menurut Schumpeter (Alma, 2005), wirausahawan adalah individu yang mendobrak sistem ekonomi yang ada dan menggerakkan perekonomian masyarakat untuk maju ke depan.

Dari berbagai definisi di atas dapat disimpulkan bahwa kewirausahaan adalah kemampuan berpikir kreatif dan berperilaku inovatif (menciptakan sesuatu yang baru dan 
berbeda) yang dijadikan dasar, sumber daya, kiat dan proses menciptakan nilai tambah barang dan jasa yang dilakukan dengan keberanian mengambil resiko. Esensi dari kewirausahaan adalah menciptakan nilai tambah di pasar melalui proses pengkombinasian sumber daya dengan cara-cara baru dan berbeda agar dapat bersaing.

Sukardi (dalam As'ad, 2003) menyatakan bahwa seorang wirausahawan yang berhasil mempunyai karakteristik sebagai berikut: (1) Supel dan fleksibel dalam bergaul, mampu menerima kritik dan mampu melakukan komunikasi yang efektif dengan orang lain; (2) Mampu dan dapat memanfaatkan kesempatan usaha yang ada; (3) Berani mengambil resiko yang telah diperhitungkan atas hal-hal yang akan dikerjakan serta menyenangi tugas-tugas yang efektif dengan orang lain; (4) Memiliki pandangan ke depan, cerdik, lihai, dapat menanggapi situasi yang berubah-ubah serta tahan terhadap situasi yang tidak menentu; (5) Mampu menemukan sesuatu yang orisinil dari pemikiran sendiri dan mampu menciptakan halhal serta kreatif; (6) Mempercayai kemampuan sendiri, kemampuan untuk bekerja mandiri, optimis dan dinamis serta memiliki kemampuan untuk menjadi pemimpin; (7) Menguasai berbagai pengetahuan maupun ketrampilan dalam menyusun, menjalankan dan mencapai tujuan organisasi usaha, manajemen umum dan berbagai bidang pengetahuan lain yang menyangkut dunia usaha; (8) Memiliki motivasi yang kuat untuk menyelesaikan tugasnya dengan baik, mengutamakan prestasi, selalu memperhitungkan faktor penghambat maupun penunjang, tekun, kerja keras, teguh dalam pendirian dan berdisiplin tinggi; dan (9) Memperhatikan lingkungan sosial untuk mencapai taraf hidup yang lebih baik bagi semua orang.

Bisnis kecil sangat penting artinya bagi perekonomian suatu negara. Sebagian besar perusahaan di Amerika Serikat mempekerjakan kurang dari 100 orang dan sebagian pekerja di Amerika Serikat dipekerjakan oleh perusahaan kecil. Sebesar $86,7 \%$ dari semua bisnis di Amerika Serikat mempekerjakan 20 karyawan atau kurang, $11 \%$ lainnya mempekerjakan antara 20-99 orang karyawan. Sebaliknya hanya $1 \%$ yang mempekerjakan 1000 atau lebih pekerja. $25,60 \%$ dari semua tenaga kerja di Amerika Serikat dipekerjakan oleh perusahaan yang memiliki karyawan kurang dari 20 orang. 29,10\% lainnya bekerja di perusahaan yang mempekerjakan 20-99 orang (Sunarto, 2007).
Berdasarkan data BPS (2001), jumlah usaha kecil di Indonesia sebanyak 14,1 juta usaha $(96,1 \%)$ dari 14,66 juta usaha yang disurvei di luar sektor pertanian. Berarti para pengusaha di Indonesia kebanyakan adalah pengusaha kecil. Dengan demikian usaha kecil di Indonesia telah memberikan kontribusi sebesar 66,1\% terhadap Pendapatan Nasional Bruto Indonesia. Hal ini menunjukkan perkembangan bisnis dan ekonomi di Indonesia sangat bergantung pada perkembangan dari bisnis yang dijalankan oleh usaha kecil.

\section{Imbalan dalam Wirausaha}

Setiap orang tertarik pada kewirausahaan karena berbagai imbalan yang dapat dikelompokkan menjadi tiga kategori dasar, yaitu: imbalan berupa laba, imbalan kebebasan dan imbalan berupa kepuasan dalam menjalani hidup.

1) Imbalan berupa laba

Laba adalah salah satu cara dalam mempertahankan nilai perusahaan. Wirausaha mengharapkan hasil yang tidak hanya mengganti kerugian waktu dan uang yang diinvestasikan, tetapi juga memberikan imbalan yang pantas bagi resiko dan inisiatif yang mereka ambil dalam mengoperasikan bisnis mereka sendiri. Dengan demikian imbalan berupa laba merupakan motivasi yang kuat bagi wirausaha tertentu.

2). Imbalan berupa kebebasan

Kebebasan untuk menjalankan perusahaannya merupakan imbalan lain bagi seorang wirausaha. Beberapa wirausaha menggunakan kebebasannya untuk menyusun kehidupan dan perilaku kerja pribadinya secara fleksibel. Seperti mengerjakan urusan mereka dengan cara sendiri, memungut laba sendiri dan mengatur jadwal sendiri.

3). Imbalan berupa kepuasan dalam menjalani hidup

Wirausaha sering menyatakan kepuasan yang mereka dapatkan dalam menjalankan bisnisnya sendiri. Pekerjaan yang mereka lakukan memberikan kenikmatan yang berasal dari kebebasan, dan kenikmatan ini merefleksikan pemenuhan kerja pribadi pemilik barang dan jasa perusahaan. Banyak perusahaan yang dikelola oleh wirausaha tumbuh menjadi besar, akan tetapi ada juga yang relatif tetap berskala kecil. 
Faktor-faktor Dalam Berwirausaha

Pada dasarnya faktor-faktor yang mempengaruhi kewirausahaan dapat dibagi menjadi dua, yaitu faktor internal dan faktor eksternal. Faktor internal merupakan faktor dari dalam individu itu sendiri, sedangkan faktor eksternal merupakan hasil interaksi individu dengan lingkungannya (Suryana, 2001 dalam Chasbiansari, 2007).

Menurut Utami (2007), faktor-faktor yang mempengaruhi minat berwirausaha meliputi dua aspek yaitu:

1) Faktor internal, terdiri dari:

a) Faktor demografi, meliputi:

(1) Usia. Perkembangan karir berjalan dengan proses perkembangan manusia.

(2) Pendidikan. Semakin banyak seseorang tertarik untuk belajar dalam dunia pendidikan, akan meningkatkan usahanya.

b) Kepribadian, meliputi:

(1) Ekstraversi

(2) Agreebleeness (kesepahaman)

(3) Berani mengambil resiko

(4) Kebutuhan berprestasi dan independen

(5) Evaluasi diri

(6) Overconfidence

c) Motif pribadi, meliputi:

(1) Motif untuk bekerja

(2) Motif untuk kreatif

2) Aspek eksternal, yaitu aspek yang berasal dari luar diri seseorang untuk melakukan wirausaha, meliputi:
a) Lingkungan keluarga

b) Lingkungan bekerja

Menurut Suryana (2001) dalam Chasbiansari (2007) faktor-faktor yang mempengaruhi kewirausahaan antara lain:

1) Faktor internal, meliputi:

a) Kebutuhan berprestasi (need for achievement)

Kebutuhan berprestasi mendorong individu untuk menghasilkan yang terbaik. Lambing dan Kuehl (2000) menyatakan bahwa tujuan yang ingin dicapai seorang wirausahawan dipengaruhi oleh kebutuhan akan berprestasinya yang mendorong individu menghasilkan yang terbaik dan biasanya memiliki inisiatif serta keinginan yang kuat untuk mengungkapkan ide-ide dalam pikirannya, menyampaikan gagasan demi mencapai suatu kesuksesan.

b) Internal locus of control
Lambing dan Kuehl (2000) menyatakan bahwa individu yang memiliki internal locus of control mempercayai bahwa kegagalan dan kesuksesan yang dialami ditentukan dari usaha yang dilakukan. Individu yakin akan kemampuan yang dimiliki dan berusaha keras mencapai tujuannya. Berdasarkan penelitian Rotter (dalam Hisrich dan Peters, 2000) terhadap wirausaha menunjukkan bahwa internal locus of control berhubungan dengan motivasi berusaha dan berkorelasi positf dengan kesuksesan dalam berkarir.

c) Kebutuhan akan kebebasan (need for independence)

Kebutuhan akan kebebasan berarti kebutuhan individu untuk mengambil keputusan sendiri, menentukan tujuan sendiri serta melakukan tindakan untuk mencapai tujuan dengan caranya sendiri. Hisrich dan Peters (2000) menyatakan bahwa seorang wirausahawan diharuskan untuk melakukan sesuatu berdasarkan caranya sendiri, sehingga memiliki kebutuhan akan kebebasan yang tinggi.

d) Nilai-nilai pribadi.

Nilai pribadi akan menjadi dasar bagi individu pada saat mengambil keputusan dalam membuat perencanaan untuk mencapai kesuksesan. Nilai pribadi yang dianut seringkali berbeda dengan nilai yang dimiliki orang lain. Oleh karena itu nilai pribadi harus disampaikan sehingga tidak menimbulkan konflik yang mendasar ketika suatu hubungan sedang berjalan. Hisrich dan Peters (2000) menyatakan beberapa penelitian menunjukkan bahwa wirausaha mempunyai sifat dasar mengenai proses manajemen dan bisnis secara umum yang membantu individu menciptakan dan mempertahankan bisnis yang dirintis. Sifat dasar meliputi nilai kemenangan bagi individu yang berarti berhasil mengaktualisasikan dirinya.

e) Pengalaman

Pengalaman diartikan pengalaman kerja individu sebelum memutuskan kewirausahaan sebagai pilihan karir. Hisrich dan Peters (2000) menyatakan bahwa pengalaman kerja mempengaruhi individu dalam menyusun rencana dan melakukan langkah-langkah selanjutnya.

Faktor eksternal, meliputi:

a) Role model 
Role model merupakan faktor penting yang mempengaruhi individu dalam memilih kewirausahaan sebagai karir. Orang tua, saudara, guru atau wirausaha lain dapat menjadi role model bagi individu. Individu membutuhkan dukungan dan nasehat dalam setiap tahapan dalam merintis usaha, role model berperan sebagai mentor bagi individu. Individu juga akan meniru perilaku yang dimunculkan oleh role model. Pentingnya role model dalam mempengaruhi pilihan karir didukung oleh penelitian Jacobowitz dan Vidler (dalam Riyanti, 2001) yang menunjukkan bahwa $72 \%$ wirausahawan negara Atlantik memiliki orang tua atau saudara wirausahawan. Individu berwirausaha dengan cara meniru orang tua atau saudara yang berwirausaha.

b) Dukungan keluarga dan teman

Dukungan dari orang dekat akan mempermudah individu sekaligus menjadi sumber kekuatan ketika menghadapi permasalahan. dukungan dari lingkungan terdekat akan membuat individu mampu bertahan menghadapi permasalahan yang terjadi.

c) Pendidikan

Pendidikan formal berperan penting dalam kewirausahaan karena memberi bekal pengetahuan yang dibutuhkan dalam mengelola usaha terutama ketika menghadapi suatu permasalahan. Sekolah atau universitas sebagai tempat berlangsungnya pendidikan formal yang mendukung kewirausahaan akan mendorong individu untuk menjadi seorang wirausaha (Hisrich dan Peters, 2000).

\section{Kerangka berpikir}

Berdasarkan dari uraian teori di atas, maka dapat dibuat kerangka berpikir penelitian ini sebagai berikut:

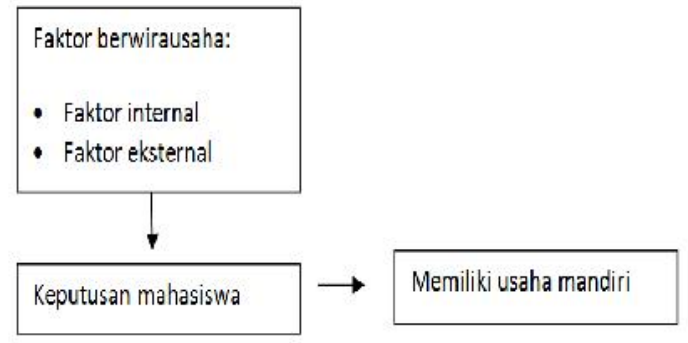

Gambar 1. Kerangka berpikir

\section{METODE PENELITIAN} Jenis Penelitian
Jenis penelitian yang digunakan adalah penelitian deskriptif, yaitu menggambarkan polapola yang konsisten dalam data, sehingga hasilnya dapat dipelajari dan ditafsirkan secara singkat dan penuh makna (Kuncoro, 2003). Tehnik yang digunakan adalah survey yaitu menyebarkan angket kepada responden untuk diisi, serta melakukan tanya jawab langsung berkaitan dengan permasalahan penelitian.

\section{Variabel penelitian}

Faktor internal, yaitu faktor yang berasal dari diri seseorang untuk melakukan suatu kegiatan. Itemitemnya yaitu: (1) Berani mengambil resiko (risk taker), (2) Internal locus of control, (3) Motivasi memperoleh pendapatan sendiri, (4) Kebebasan, dan (5) Ide kreatif.

Faktor eksternal, yaitu faktor yang berasal dari luar diri seseorang untuk melakukan suatu kegiatan. Item-itemnya antara lain: (1) Pengaruh role model, (2) Dukungan keluarga dan teman, (3) Kesempatan, (4) Kepuasan menjalani hidup, dan (5) Pendidikan.

Keputusan mahasiswa memiliki usaha mandiri, dengan item-item: (1) Berdasarkan intuisi (perasaan yang sifatnya subyektif), (2) Berdasarkan pengalaman, (3) Berdasarkan fakta yang ada di lapangan, (4) Berdasarkan wewenang, dan (5) Berdasarkan rasional

\section{Populasi dan Sampel}

Populasi adalah keseluruhan obyek penelitian yang hendak diteliti. Populasi dalam penelitian ini adalah mahasiswa STIE Malangkucecwara Malang angkatan 2013-2015 sejumlah 1079 orang. Sampel adalah suatu himpunan bagian (subset) dari unit populasi (Kuncoro, 2003). Dengan besarnya prosentasi sampel $5 \%$ dari populasi, maka sampel penelitian adalah sebanyak 54 mahasiswa. Tehnik pengambilan sampel menggunakan purposive sampling, yaitu mengambil sampel dengan menggunakan kriteria tertentu. Adapun kriteria sampel penelitian adalah mahasiswa yang memiliki usaha mandiri.

\section{Metode Analisis Uji validitas.}

Menurut Santoso (2002), uji validitas digunakan untuk mengukur sah atau valid tidaknya suatu kuisioner. Kuesioner dikatakan valid atau sahih jika mampu mengukur apa yang diinginkan oleh peneliti serta dapat mengungkapkan data dari peubah yang diteliti secara tepat. Teknik yang digunakan untuk 
mengukur validitas dengan mengkorelasikan skor total item dengan skor masing-masing item. Dengan kriteria apabila probabilitas dari masingmasing item kurang dari 0,05, maka item tersebut dikatakan valid.

\section{Metode analisis deskriptif}

Penelitian yang dilakukan dikategorikan sebagai penelitian deskriptif karena bertujuan untuk mengumpulkan fakta dan menguraikannya secara menyeluruh dan teliti sesuai dengan persoalan yang akan dipecahkan. Penelitian deskriptif adalah menggambarkan pola-pola yang konsisten dalam data, sehingga hasilnya dapat dipelajari dan ditafsirkan secara singkat dan penuh makna (Kuncoro, 2003).

\section{HASIL PENELITIAN \\ Deskripsi Responden}

Mahasiswa dengan jenis kelamin perempuan sebesar 33,7\% (33 orang), sedangkan laki-laki 21,4\% (21 orang). Berarti mahasiswi lebih tertarik menjalankan wirausaha sambil kuliah daripada mahasiswa laki-laki. Hal ini disebabkan karena mereka lebih menyukai melakukan bisnis untuk mengisi waktu luang dan mendapatkan income sampingan selain uang saku dari orang tua. Selain itu mahasiswi lebih supel dan luwes dalam menawarkan produk yang dijual.

Mayoritas mahasiswa yang menjalankan wirausaha berusia 21-22 tahun sebesar 44.4\% (24 orang). Berarti mereka termasuk angkatan 2014/2015 atau sedang berada di semester 3-4. Hal ini menunjukkan bahwa mahasiswa berada pada usia produktif dan kreativitasnya tinggi. Serta memiliki semangat yang tinggi untuk menjalankan usaha mandiri selain menempuh perkuliahan. Selain itu jaringan relasi dan informasi juga sudah mulai luas sehingga mempermudah kelancaran usaha yang mereka tekuni.

Mayoritas mahasiswa adalah angkatan 2014/2015 sebanyak 25 orang $(25.5 \%)$. Berarti mereka sudah menempuh kuliah di tahun kedua atau semester 3-4. Di semester ini, mereka telah mendapatkan bekal teori kewirausahaan dan manajemen di semester 1 lalu. Sehingga dirasa sudah memiliki bekal pengetahuan untuk memulai usaha mandiri, walau dalam scope yang kecil. Mayoritas mahasiswa melakukan pengeluaran sebulan sebesar Rp 1-2 juta. Dengan pengeluaran sebesar itu maka wajar mendorong mahasiswa mencari usaha sampingan untuk dapat memperoleh pendapatan lain guna mencukupi kebutuhannya.

Mayoritas mahasiswa bertempat tinggal di pondokan (kost) sebesar 42,6\% (23 mahasiswa). Berarti sebagian besar mereka adalah anak perantauan. Hal ini mendorong mereka untuk menjalankan wirausaha agar memiliki uang saku lebih guna mencukupi biaya hidup, ataupun menambah tabungan karena jauh dari orang tua. Mayoritas pekerjaan orang tua mahasiswa adalah pegawai swasta dan wiraswasta yaitu masingmasing sebanyak 21 orang atau $21.4 \%$. Jadi mahasiswa sebenarnya telah terinspirasi dari orang tuanya dengan melihat mereka melakukan usaha bisnis sejak muda. Salah satu faktor penunjang kewirausahaan adalah dari keteladanan. Dalam hal ini keteladanan dilihat dari pekerjaan orang tuanya.

IPK mahasiswa mayoritas sudah baik, yaitu di atas 3.00 sebesar 36 orang (36\%). Hal ini berarti bahwa walau mereka melakukan aktivitas berwirausaha, ternyata tidak membuat prestasi akademis menurun. Artinya, mereka tidak terpengaruh dengan kegiatan time management yaitu membagi waktu yang seimbang antara kuliah dengan berbisnis. Mayoritas mahasiswa tidak memiliki pengalaman dalam berwirausaha yaitu sebesar 40 orang $(40.8 \%)$. Tetapi hal ini tidak menyurutkan minat mereka untuk berbisnis sambil kuliah. Justru dengan kondisi seperti ini akan menempa mental mereka dalam berusaha, sehingga kelak jika terjun ke dunia kerja nyata mereka tidak kaget dan bisa bertahan berdasarkan pengalaman mereka saat ini.

Mayoritas mahasiswa tidak pernah mengikuti kegiatan kewirausahaan, seperti pelatihan, workshop, seminar, dan lain-lain sebesar 18 orang $(18,4 \%)$. Namun hal itu tidak membuat nyali mahasiswa ciut atau patah semangat. Dengan kondisi seperti ini akan mendorong mereka untuk lebih aktif lagi mengikuti kegiatan kewirausahaan, baik berupa pelatihan, workshop maupun seminar.

\section{Uji Validitas}

Teknik yang digunakan untuk mengukur validitas dengan mengkorelasikan skor total item dengan skor masing-masing item. Dengan kriteria apabila probabilitas dari masing-masing item kurang dari 0,05, maka item tersebut dikatakan valid. Sehingga dapat dilanjutkan ke analisis berikutnya.

\section{Analisis Deskriptif Variabel Faktor Internal Berani Mengambil Resiko}

Mayoritas responden menyatakan sangat setuju (23 orang atau $23.5 \%$ ) bahwa mental yang harus dimiliki seorang pewirausaha adalah berani mengambil resiko. Prinsipnya adalah jika tidak berani mencoba mulai sekarang, kapan lagi. Oleh 
karenanya walau di luar persaingan cukup ketat, pewirausaha tidak boleh merasa gentar. Kegagalan adalah sukses yang tertunda. Di usia yang masih belia, mahasiswa berani mengambil resiko terjun ke dunia entrepreneur.

\section{Internal Locus of Control}

Mayoritas responden menyatakan setuju (28 orang atau $28,6 \%$ ) bahwa faktor internal dalam berwirausaha adanya internal locus of control. Mereka percaya bahwa kegagalan dan kesuksesnan yang dialami ditentukan dari usaha pribadi yang dilakukan. Mereka yakin akan kemampuan yang dimiliki, serta berusaha keras untuk mencapai tujuannya.

\section{Motivasi Memperoleh Pendapatan Sendiri}

Mayoritas responden menyatakan setuju (24 orang atau $24.5 \%$ ) bahwa faktor internal berwirausaha adalah untuk memperoleh pendapatan sendiri. Seperti diketahui bahwa mahasiswa memiliki banyak sekali kebutuhan, seperti: uang kuliah, uang jajan, uang makan, dan aktivitas lain. Bahkan untuk mahasiswa yang hidup jauh dari orang tua dan harus kost atau kontrak rumah, mereka harus pintar-pintar menghemat uang, bahkan mencari cara agar bisa memperoleh pendapatan sampingan. Oleh karena mereka tidak ingin menambah beban orang tua, maka hal ini mendorong mereka untuk melakukan wirausaha untuk bisa mencukupi kebutuhan mereka setiap bulan, dan dapat menambah tabungan.

\section{Kebutuhan akan Kebebasan}

Mayoritas responden menyatakan setuju (29 orang atau 29.6\%) bahwa faktor internal berwirausaha adalah kebutuhan akan kebebasan. Maksud dari kebutuhan akan kebebasan berarti kebutuhan mahasiswa untuk mengambil keputusan sendiri, menentukan tujuan sendiri serta melakukan tindakan untuk mencapai tujuan dengan caranya sendiri. Seorang wirausahawan diharuskan untuk melakukan sesuatu berdasarkan caranya sendiri, sehingga memiliki kebutuhan akan kebebasan yang tinggi. Selain itu, kebebasan dalam konteks ini adalah kebebasan menjadi bos untuk diri sendiri, kebebasan mengatur waktu, dan kebebasan memperoleh pendapatan.

\section{Ide Kreatif}

Mayoritas responden menyatakan setuju (32 orang atau 32.7\%) bahwa dalam berwirausaha dibutuhkan ide kreatif. Dalam persaingan usaha saat ini yang sangat ketat, sangatlah dibutuhkan kreativitas dalam berusaha. Entah dalam hal adanya keunikan produk atau jasa yang ditawarkan ke konsumen, atau pemasaran yang saat ini sudah banyak menggunakan kekuatan sosial media, atau layanan (service) kepada konsumen yang prima, dan lain sebagainya. Semakin kreatif suatu usaha, maka akan semakin banyak konsumen yang dapat diraih.

\section{Analisis Deskriptif Faktor Eksternal Pengaruh Role Model}

Mayoritas responden menyatakan setuju (28 orang atau $28.6 \%$ ) bahwa dalam berwirausaha dibutuhkan pengaruh adanya role model. Orang tua, saudara, dosen, guru atau wirausaha lain dapat menjadi role model bagi mahasiswa. Mereka membutuhkan dukungan dan nasehat dalam setiap tahapan dalam merintis usaha, role model berperan sebagai mentor. Mahasiswa juga akan meniru perilaku yang dimunculkan oleh role model.

\section{Dukungan Keluarga dan Teman}

Mayoritas responden (23 orang atau 23.5\%) menyatakan bahwa dukungan keluarga dan teman sangat penting artinya dalam kegiatan berwirausaha. Dukungan dari orang terdekat akan mempermudah mahasiswa, sekaligus menjadi sumber kekuatan ketika menghadapi permasalahan. Dukungan dari lingkungan terdekat akan membuat mereka mampu bertahan menghadapi permasalahan yang terjadi.

\section{Kesempatan}

Mayoritas responden (29 orang atau 29.6\%) menyatakan setuju bahwa kesempatan merupakan faktor eksternal pendukung kewirausahaan. Dengan melakukan time management yang baik, mahasiswa dapat mempunyai kesempatan walaupun sedikit waktu luangnya untuk melakukan kegiatan wirausaha. Seperti kata pepatah, time is money. Sekecil apapun waktu luang yang ada, itu berharga artinya. Kesempatan ini juga dapat diartikan, bahwa mahasiswa melihat adanya peluang usaha yang baik sehingga melakukan kegiatan ini di sela-sela kesibukannya kuliah.

\section{Kepuasan Menjalani Hidup}

Mayoritas responden menyatakan setuju (33 orang atau 33.7\%) bahwa kepuasan menjalani hidup merupakan faktor eskternal dalam berwirausaha. Di usia muda seperti mereka, dapat menghasilkan pendapatan sendiri dengan usaha sendiri akan menambah kepuasan hidup mereka. Karena mereka dapat memenuhi kebutuhan hidupnya dan bisa menambah tabungan mereka di luar bantuan rutin bulanan dari orang tua. 
Semakin kepuasan bertambah, maka semakin giat mereka menjalankan aktivitas ini.

\section{Pendidikan}

Mayoritas responden (29 orang atau $29.6 \%$ ) setuju bahwa pendidikan merupakan faktor pendorong berwirausaha. Pendidikan formal berperan penting dalam kewirausahaan karena memberi bekal pengetahuan yang dibutuhkan dalam mengelola usaha terutama ketika menghadapi suatu permasalahan. Sekolah atau universitas sebagai tempat berlangsungnya pendidikan formal yang mendukung kewirausahaan akan mendorong individu untuk menjadi seorang wirausaha.

\section{Deskripsi Analisis Keputusan Berwirausaha Berdasarkan Intuisi}

Mayoritas responden (28 orang atau $28.6 \%$ menyatakan setuju bahwa intuisi merupakan hal pendorong dalam pengambilan keputusan berwirausaha. Pengambilan keputusan berdasarkan intuisi adalah pengambilan keputusan yang berdasarkan perasaan yang sifatnya subyektif. Agar pengambilan keputusan berwirausaha berdasarkan intusi ini dapat menghasilkan keputusan yang tepat, maka perlu didukung dengan hal-hal penunjang lainnya seperti riset pemasaran yang akurat dan didasarkan atas intuisi yang positif.

\section{Berdasarkan Pengalaman}

Mayoritas responden (26 orang atau $26.5 \%$ ) menyatakan setuju bahwa pengalaman sebagai faktor pengambilan keputusan mahasiswa berwirausaha. Dengan pengalaman yang dimiliki, pewirausaha telah memahami seluk beluk aktivitas usaha, baik secara internal maupun eksternal. Selain itu dengan pengalaman yang dimiliki, tentu saja mereka mempunyai banyak pengetahuan dan wawasan mengenai bisnis yang sedang digeluti. Dengan pengalaman pula, relasi bisnis telah dirajut. Sehingga mereka memiliki network yang luas. Pengambilan keputusan berdasarkan pengalaman memiliki manfaat bagi pengetahuan praktis, karena dengan pengalaman yang dimiliki seseorang, maka dapat memperkirakan keadaan sesuatu, dapat memperhitungkan untung-ruginya dan baikburuknya keputusan yang akan dihasilkan.

\section{Berdasarkan fakta yang terjadi di lapangan}

Mayoritas responden tidak setuju (26 orang atau $26.5 \%$ ) bahwa fakta yang terjadi di lapangan sebagai hal-hal yang menghambat mahasiswa berwirausaha. Kondisi rugi atau gagal usaha bukanlah hal-hal yang perlu ditakuti oleh seorang pewirausaha. Justru dengan kegagalan yang dialami, akan menjadi cambuk bagi mereka untuk terus bangkit, berinovasi dan bahkan bisa membuka lapangan usaha kerja yang baru. Jika fakta yang dialami adalah keuntungan yang besar, maka hal ini akan memacu pewirausaha untuk bisa mempertahankan bisnis mereka dan tetap mengatur strategi usaha agar terus bisa eksis di bidang usahanya tersebut. Pengambilan keputusan berdasarkan data dan fakta empiris dapat memberikan keputusan yang sehat, solid dan baik. Dengan fakta, tingkat kepercayaan terhadap pengambil keputusan dapat lebih tinggi, sehingga orang dapat menerima keputusan yang dibuat itu dengan rela dan lapang dada.

\section{Berdasarkan Wewenang}

Mayoritas responden (31 orang atau $31.6 \%$ ) setuju bahwa pengambilan keputusan berwirausaha adalah karena wewenang. Dengan menjadi pewirausaha maka kendali sepenuhnya (wewenang) terletak pada diri mereka sendiri. Mereka menjadi bos untuk diri sendiri. Pengambilan keputusan berdasarkan wewenang biasanya dilakukan oleh pimpinan terhadap bawahannya, atau oleh orang yang lebih tinggi kedudukannya kepada orang yang lebih rendah kedudukannya. Hasil keputusannya dapat bertahan dalam jangka waktu yang cukup lama dan memiliki otentisitas (otentik), tetapi dapat menimbulkan sifat rutinitas, mengasosiasikan dengan praktek diktatorial dan sering melewati permasalahan yang seharusnya dipecahkan sehingga dapat menimbulkan kekaburan

\section{Berdasarkan Rasional}

Mayoritas responden menyatakan setuju (31 orang atau $31.6 \%$ ) bahwa pengambilan keputusan berwirausaha didasarkan atas rasionalitas. Pada pengambilan keputusan yang berdasarkan rasio, keputusan yang dihasilkan bersifat objektif, logis, lebih transparan dan konsisten untuk memaksimumkan hasil atau nilai dalam batas kendala tertentu, sehingga dapat dikatakan mendekati kebenaran atau sesuai dengan apa yang diinginkan. Pengambilan keputusan secara rasional ini berlaku sepenuhnya dalam keadaan yang ideal. Jenis bidang usaha yang akan menjadi aktivitas berwirausaha disesuaikan dengan peluang usaha, kemampuan internal dan eksternal, serta sesuai dengan sumber daya yang dimiliki. 


\begin{abstract}
Deskripsi Faktor Penghambat Usaha Mandiri
Mayoritas responden (23 orang atau $23.5 \%)$ menyatakan bahwa faktor penghambat wirausaha mahasiswa adalah kegagalan usaha. Hal ini disebabkan banyak faktor, antara lain: kurang pengalaman, kurang relasi, permodalan yang tidak mencukupi, kesalahan manajemen, perencanaan usaha yang kurang matang, survey pasar yang kurang akurat, pemasaran yang kurang gencar, produk kurang inovatif dan tidak memiliki nilai lebih dibandingkan produk pesaing, dan lain-lain.
\end{abstract}

\section{Deskripsi Dukungan Wirausaha}

Mayoritas responden (42 orang atau $42,9 \%)$ menyatakan bahwa mayoritas yang mendukung kegiatan usaha mandiri mahasiswa adalah orang tua. Dapat dipahami bahwa orang tua adalah orang terdekat mahasiswa. Tentu saja merekalah yang mensupport penuh usahanya, baik materiil maupun non materiil.

\section{PEMBAHASAN}

Dari paparan deskriptif di atas, diketahui bahwa mayoritas jenis kelamin mahasiswa memiliki usaha mandiri di STIE Malangkucecwara Malang adalah wanita, berusia 21-22 tahun, sedang kuliah di tingkat dua atau semester 3 (angkatan 2014/2015), anak perantauan (tinggal di kos-kos an), IPK di atas 3, tidak memiliki pengalaman berwirausaha sebelumnya, dan tidak pernah mengikuti kegiatan wirausaha baik berupa seminar, pelatihan, ataupun workshop. Faktor penghambat wirausaha adalah kegagalan usaha, sedangkan dukungan terbesar adalah dari orang tua.

Faktor internal mahasiswa memiliki usaha mandiri didasarkan atas berani mengambil resiko, internal locus of control, motivasi memiliki pendapatan sendiri, kebutuhan akan kebebasan, dan ide kreatif. Sedangkan faktor eksternal yang mendorong mahasiswa memiliki usaha mandiri adalah: pengaruh role model, dukungan keluarga dan teman, kesempatan, kepuasan menjalani hidup, dan pendidikan. Sedangkan keputusan mahasiswa memiliki usaha mandiri didasarkan oleh intuisi, pengalaman, fakta yang terjadi di lapangan, wewenang, dan rasional.

Hal ini senada dengan penelitian yang dilakukan oleh Indarti, Nurul dan Rokhima Rostiani (2008). Hasil penelitian membuktikan bahwa self-efficacy menjadi faktor kunci yang mempengaruhi minat berwirausaha pada mahasiswa Norwegia. Sedangkan latar belakang pendidikan menjadi faktor utama pada mahasiswa Indonesia.

Penelitian Yulia, Wasa dan Dwi Endah Kusrini (2010) yang mengambil obyek mahasiswa berwirausaha di ITS Surabaya membuktikan bahwa hanya sebagian kecil saja mahasiswa yang menjalankan usaha sampingan selain kuliah, sebagian besar berasal dari luar Surabaya, tingkat IPK berkisar $3.00-3.50$, dan banyak di antara mereka yang pernah mengikuti kegiatan kewirausahaan tetapi tidak pernah punya pengalaman berwirausaha. Variabel IPK, kepribadian berani mengambil resiko, evaluasi diri dan pengaruh lingkungan keluarga secara signifikan berpengaruh terhadap kemepilikan usaha mandiri mahasiswa ITS.

Zulkifli (2011) dalam penelitiannya membuktikan bahwa faktor tersebut adalah kepercayaan diri, orientasi terhadap tugas dan hasil, berani mengambil resiko, kepemimpinan dan orisinalitas. Sedangkan penelitian Ifham, Ahmad dan Avin Helmi (2011) meneliti tentang hubungan kecerdasan emosi dan kewirausahaan pada mahasiswa. Hasil penelitian menunjukkan bahwa kecerdasan emosi meliputi: emotional literacy, emotional fitness, emotional depth, dan emotional alchemy. Sedangkan kewirausahaan meliputi: kemampuan melihat peluang bisnis, memiliki kepercayaan diri dan berperilaku baik terhadap dirinya dan lingkungan, gaya kepemimpinan, adanya inisiatif, kreativitas dan inovasi, mampu menjadi pekerja keras, memiliki visi yang luas dan optimisme tinggi, berani mengambil resiko, dan sensitif terhadap kritik membangun. Penelitian Chasbiansari, Dyas (2007) membuktikan bahwa terdapat hubungan positif dan signifikan antara kompetensi sosial dan kewirausahaan pada mahasiswa Universitas Diponegoro Semarang.

\section{KESIMPULAN DAN SARAN Kesimpulan}

Tujuan penelitian ini adalah untuk mengetahui keputusan mahasiswa memiliki usaha mandiri STIE Malangkucecwara Malang ditinjau dari faktor internal dan eksternal. Jenis penelitian adalah deskriptif. Sampel penelitian sejumlah 54 orang mahasiswa dari angkatan 2013-2015. Uji validitas menunjukkan bahwa seluruh item-item nya adalah valid, sehingga dapat dilanjutkan pada analisis selanjutnya. 
Hasil penelitian membuktikan bahwa mayoritas jenis kelamin mahasiswa memiliki usaha mandiri di STIE Malangkucecwara Malang adalah wanita, berusia 21-22 tahun, sedang kuliah di tingkat dua atau semester 3 (angkatan 2014/2015), anak perantauan (tinggal di kos-kos an), IPK di atas 3, tidak memiliki pengalaman berwirausaha sebelumnya, dan tidak pernah mengikuti kegiatan wirausaha baik berupa seminar, pelatihan, ataupun workshop.

Faktor internal mahasiswa memiliki usaha mandiri didasarkan atas berani mengambil resiko, internal locus of control, motivasi memiliki pendapatan sendiri, kebutuhan akan kebebasan, dan ide kreatif. Sedangkan faktor eksternal yang mendorong mahasiswa memiliki usaha mandiri adalah: pengaruh role model, dukungan keluarga dan teman, kesempatan, kepuasan menjalani hidup, dan pendidikan. Sedangkan keputusan mahasiswa memiliki usaha mandiri didasarkan oleh intuisi, pengalaman, fakta yang terjadi di lapangan, wewenang, dan rasional.

Faktor penghambat terbesar dalam berwirausaha adalah kegagalan usaha, dan pendukung terbesar mahasiswa berwirausaha adalah orang tua. Hasil penelitian ini didukung oleh penelitian terdahulu antara lain: Indarti, Nurul dan Rokhima Rostiani (2008), Yulia, Wasa dan Dwi Endah Kusrini (2010), Zulkifli (2011), Ifham, Ahmad dan Avin Helmi (2011), dan Chasbiansari, Dyas (2007).

\section{Saran-saran}

Kegiatan wirausaha mandiri mahasiswa di STIE Malangkucecwara Malang sudah mulai menggeliat. Oleh karenanya perlu ada dukungan dari pihak kampus dalam memfasilitasi aktivitas mereka. Pihak manajemen kampus dapat melakukan kegiatan bazaar atau pameran hasil produk mahasiswa untuk dijualbelikan, mengikutkan mereka dalam ajang pameran wilayah Kotamadya Malang, memberikan pelatihan gratis dengan memanggil narasumber praktisi yang dapat memberikan wawasan ilmu kepada mereka, memberikan workshop dan seminar tentang kewirausahaan. Dosen dalam melakukan proses belajar mengajar dapat menyelipkan motivasi kepada mahasiswa untuk berani berwirausaha.

Untuk mahasiswa, karena aktivitas berwirausaha ini dilakukan bersamaan dengan kegiatan perkuliahan, maka seyogyanya mereka harus pintar-pintar melakukan time management agar kedua aktivitas ini dapat berjalan beriringan. Fokus utama adalah kuliah, dan mengisi waktu luang yang positif dengan menjalankan bisnis sendiri.

Orang tua sebagai supporter utama mahasiswa, seyogyanya juga mendukung aktivitas positif ini. Karena banyak sekali manfaat yang dipetik mahasiswa dalam berwirausaha. Antara lain: memperoleh uang sendiri untuk jajan atau menabung, mengasah jiwa organisasi, mengasah jiwa bisnis, mengasah kemampuan berkomunikasi dan memecahkan masalah, menambah luasnya relationship, mempersiapkan mahasiswa untuk berkecimpung ke dunia kerja nyata.

Pemerintah dapat terus mendukung kegiatan wirausaha mahasiswa dengan mengeluarkan berbagai macam hibah mahasiswa yang kompetitif, sehingga mereka terpacu dan termotivasi melakukan kegiatan ini. Selain itu, meluncurkan program-program pelatihan dan workshop secara gratis melalui Disperindag untuk menambah skill dan pengetahuan mahasiswa. Pemerintah juga dapat meluncurkan program bantuan pendanaan bagi usaha kecil, untuk usaha mahasiswa yang membutuhkan modal banyak.

\section{DAFTAR PUSTAKA}

1. Chasbiansari, Dyas. 2007. Kompetensi Sosial dan Kewirausahaan Mahasiswa Universitas Diponegoro Semarang. Penelitian dipublikasikan. Diakses tanggal 28 Maret 2016.

2. Yulia, Wasa dan Dwi Endah Kusrini. 2010. Analisis Karakteristik Mahasiswa dan Faktor-faktor Yang Berpengaruh Terhadap Kepemilikan Usaha Mandiri Mahasiswa ITS. Penelitian dipublikasikan. Diakses tanggal 28 Maret 2016.

3. www.ditkelembagaandikti.net/pedoman/143-program-mahasiswawirausaha. Program Mahasiswa Wirausaha Bagi Perguruan Tinggi Negeri. Diakses tanggal 28 Maret 2016.

4. http://wardoyo.staff.gunadharma.ac.id. Kewirausahaan. Diakses tanggal 28 Maret 2016.

5. Badan Pusat Statistik. 2008. Angka statistik pengangguran.

6. www.mediaindonesia.com. 2010. Angka pengangguran di Indonesia. Diakses tanggal 29 Maret 2016. 
7. Ifham, Ahmad dan Avin F Helmi. Hubungan Kecerdasan Emosi dengan Kewirausahaan pada Mahasiswa. Penelitian dipublikasikan. Diakses tanggal 28 Maret 2016.

8. http://akhmadsudrajat.wordpress.com. 2010. Konsep Dasar Pengambilan Keputusan. Diakses tanggal 2 April 2016.

9. http://jarno.web.id. 2011. Awal Tahun 2011 Pengangguran Masih 9,25 juta. Diakses tanggal 29 Maret 2016.

10. As'ad, Moh. 2002. Seri Ilmu Sumber Daya Manusia: Psikologi Industri. Edisi 4. Liberty. Yogyakarta.

11. Meredith, Geoffrey G, et al. 2000. Kewirausahaan: Teori dan Praktek. Seri terjemahan. Pustaka Binaman Pressindo. Jakarta.

12. Nasution, Arman Hakim, dkk. 2001. Membangun Spirit Entrepreneur Muda Indonesia, Suatu Pendekatan Praktis dan Aplikatif. Gramedia. Jakarta

13. Utami, Erlita Dhiah. 2007. Faktor-faktor yang Mempengaruhi Minat Berwiraswasta (Studi Deskriptif pada Usahawan Rental Komputer di Sekaran Gunung Pati Semarang). Penelitian dipublikasikan. http://digilib.unnes.ac.id. Diakses tanggal 28 Maret 2016.

14. Yohnson, dkk. 2003. Motivasi Alumnus UK Petra Menjadi Entrepreneurs. Jurnal Manajemen dan Kewirausahaan vol 5 no 2 September 2003. Diakses tanggal 28 Maret 2016.

15. Sunarto. 2007. Manajemen. Penerbit Amus. Yogyakarta.

16. Siswanto, HB. 2008. Pengantar Manajemen. Penerbit PT Bumi Aksara. Jakarta.

17. Sule, Ernie Tisnawati dan Kurniawan Saefullah. 2008. Pengantar Manajemen. Penerbit Prenada media. Jakarta.

18. Williams, Chuck. 2001. Manajemen. Edisi terjemahan. Salemba Empat. Jakarta.

19. Kuncoro, Mudrajad, 2003, Metode Riset Untuk Bisnis dan Ekonomi (Bagaimana meneliti dan menulis tesis ?), Erlangga, Jakarta. 